https://ejournal.uniska-kediri.ac.id/index.php/PROFICIENCY

\title{
THE EFFECTIVENESS OF TEACHING SPEAKING BY USING WHATSAPPS OF TENTH GRADE STUDENTS AT MAN 4 KEDIRI
}

\author{
By: Estika Sari
}

\begin{abstract}
The aim of the research was to analyze whether Whatshapp Messenger (WA) was effective to be used in teaching speaking descriptive at the tenth grade of MAN 4 Kediri. This research was quantitative research approach, whereas the research design used was posttest-only control-design. This research used two classes which became experimental group (MIA 3) and control group (MIA 4). In experimental group was taught by using Whatshapp Messenger, whereas control group was taught without Whatshapp Messenger. The instruments used in the research was written test. The procedure lasted 3 meetings and 1 meeting to do test. The result of t-test showed that: the mean score of experimental group $(\mathrm{M}=$ $81.15)$ was higher than control group $(\mathrm{M}=70.29)$, and independent-samples t-test which values of the sig. 2 -tailed was $0 \%$ or 0.000 and $0.000<0,05$. Thus, it could be concluded that Whatshapp Messenger was effective in teaching and learning of English speaking descriptive text. This result suggests that the speaking aspects which the students significantly outperformed were (1) Pronunciation (2) Vocabulary (3) Grammatical (4) Fluency (5) Comprehension and (6) Expression.
\end{abstract}

Key word: effectiveness, descriptive text, speaking, WhatsApp messenger (WA)

\section{INTRODUCTION}

Speaking is one of the four basic skills in learning foreign language besides listening, reading and writing. Speaking is one of the language skills that should be mastered by language learning. By speaking people can make a good communication to the others. The success language learner is measured by their ability in carrying out conversation in daily life; therefore, speaking is a main part of language, because the fluent speaking will be a positive impact for all people in studying language. Hence, in teaching and learning of language, speaking should be the first purpose in developing language in all levels of education whether elementary school, junior and senior high school and even in a university.

According to David Haris (1974:81) in Yuddin (2008:2) stated that speaking is a complex skill requiring the simultaneous use of a number of different abilities that often develop at different rates. Speaking is more difficult to master, but having the ability to speak English is one of the important requirements in learning language. Speaking is one of key to communicate in English language. By mastering speaking skill, they can carry out conversation with others, give idea and change the information with interlocutor and people are able 
to know the situation that happens in the world. This reality makes teachers and parents think that speaking skill should be mastered by their student and children. The main point of speaking is being able to deliver some speech in every context of communication. It means that mastering speaking in studying language is the most important part because people can be said of having a good language when they speak fluently. In other words, speaking is real evidence to language learner in mastering it.

Students may find difficulties in expressing their ideas in speaking because of some factors, such as limited vocabularies, grammar confusion, or lack of confidence. Some difficulties occur when they have low scores in speaking; have problems with grammar; arrange sentences; manage their fluence; have poor spelling skills, and have limited vocabularies or ideas. We can say that speaking problems are more complex than writing because the students must arrange, speak, think, compose, and all while they have to use proper grammar and spelling. The researcher needs the media to facilitate and make students interested in learning speaking. Sometimes, students feel shy and unconfident when they have to speak in front of their friends in the class room. Studying out of class room makes students has more new ideas because they can be more fokus and has many times to explore their skill.

A part from adjusting the teaching style to overcome learning problems and to achieve learning goals, the teacher should opt to integrate modern technology in order to provide better classroom teaching. Technology is made to facilitate every human's need, but now along with its development, its function is taken over. Now technology can be used as a media or tool in English language teaching.

Educational media is widely interpreted as any person, material, equipment or events that establish conditions allowing students to acquire the knowledge, skills, and attitude (Arsyad, 2013). It is anything that can be used to deliver the message so that it can stimulate the thoughts, feelings, actions, interest, and attention of students such that the learning process happens to them. One of the benefits of media usage is to upgrade students' motivation and interest in learning English. The other benefit is that teaching aid is designed to help teachers to save their time and effort. The media used is mobile phone.

Mobile phone is one of communication technology which helps human to get information faster. It has become a crucial part of our daily life nowadays. The use of it is not only to make calls or messages, but also to share, to create, and to entertain with voice, script, picture, music, and video. In line with its development, its name is changed to smartphone. One of the aplication in smartphone is playstore. In the playstore people can download many aplications such as facebook, opera mini, twitter, path, instagram, kakao talk, wechat, instagram and whatsapp. From all operating system in smartphone that can be downloaded in playstore, there are some applications which are used as a tool to communicate. 
https://ejournal.uniska-kediri.ac.id/index.php/PROFICIENCY

Internet chat rooms are the most effective, convenient, and widely used as instruments for communication globally. One of them is WhatsApp Messenger (WA).

WhatsApp Messenger is a wellknown application among students and teachers. It is a proprietary, cross-platform, encrypted instant messaging client for smartphones. It uses the internet to make voice calls, video calls; send text messages (chatroom), documents, images, videos, location, audio files, phone contacts, and voice notes to other using standard cellular mobile numbers. One billion people are reported as active users of WhatsApp Messenger as from September 2016 based on Wikipedia data. Whatsapp messenger is chosen because of its popularuty and its practical use. Most of students use whatsapp as a media to communicate one another. The feature that used in whatsapp as a media is chatroom bacause in chatroom user can send and recieve messages, pictures or vidios.

The increased popularity of social networking sites and mobile applications has led to uptake in education. In fact, smartphones are mostly used to send messages and to access internet. This chance is used as a field to optimize the usage of smartphones, especially WhatsApp Messenger. If smartphones are only used by the students to send message, to make a phone call, to access internet, and as social networking media, its usage cannot be optimized by them yet. Hence, they had better use it as a tool in learning activities.

Learning takes place in and outside the classroom. Learning outside the classroom is considered as a self-organized learning environment for the students where they can learn in their own place and take participation in online discussion via WhatsApp Messenger. Communication between teacher and students via group discussion in WhatsApp Messenger is expected to give positive development in English language teaching and students' speaking achievement.

Based on the explanation above the researcher tries to conduct a research in the title: "The Effectiveness of Teaching Speaking by Using whatsApps of tenth grade Students at MAN 4 KEDIRI"

\section{METHODS}

The research method used in this research was Posttest-Only Control-Group Design. This research used two classes which were randomly chosen; they were control group and experimental group. The sequence, taken from (Creswell, 2014:193) is.

Table 3.1 Research Design

\begin{tabular}{|c|c|c|}
\hline & Treatment & Test \\
\hline Experimental Class & $\checkmark$ & $\checkmark$ \\
\hline Control Class & - & $\checkmark$ \\
\hline
\end{tabular}

MAN 4 Kediri was selected as the research are. It is located in $\mathrm{Jl}$. Melati No.14, Krecek, Badas, Kediri East Java in the academic year 2017 - 2018. In this research, choosing the class which becomes treatment and control class was using random sampling, and The tenth grade of MAN 4 Kediri has 10 classes. Here the researcher got two classes. They are MIA 3 and MIA 4. MIA 3 as 
https://ejournal.uniska-kediri.ac.id/index.php/PROFICIENCY

experimental class and MIA 4 as control class. Each class consists of 34 students. It means that the total subjects in this research are 68 students.

The instrument used in this research was a writing test. In this research took one of the test, namely post-test only. The test is speaking test. The students have to describe their idol. The maximum time is arround five minutes. The test administered for control and experimental group was the same. The purpose of the test was to know the students' speaking achievement by describing their idol. The steps for collecting data were: 1) Giving a test to students, 2) Distributing the test to students, 3) Giving instructions before students doing test, 4) Making the vidio based on the intruction in the test, 5) The duration of their vidio is maximum three minutes, 6) Assesing the students' test and giving the students' score, and 7) The score of students' test analyzed by using SPSS 22 version.

A. The validity of instrument

The result of SPSS would show us two signs, those were one $\operatorname{star}(*)$ and two stars $(* *)$. One star meant that the aspects were valid enough and two stars meant that aspects were very valid. The aspects given were supposed to be valid.

The validity values of each aspect were; (1) Pronunciation (2) Vocabulary (3) Grammatical (4) Fluency (5) Comprehension and (6) Expression.
Table 3.2 Validity Analysis

\begin{tabular}{|c|c|c|}
\hline \multicolumn{3}{|c|}{ Correlations } \\
\hline & & TOTAL \\
\hline \multirow{3}{*}{ Pronunciation } & Pearson Correlation & ,360* \\
\hline & Sig. (2-tailed) & 037 \\
\hline & $\mathrm{N}$ & 34 \\
\hline \multirow{3}{*}{ Vocabulary } & Pearson Correlation &, $570^{* * *}$ \\
\hline & Sig. (2-tailed) & 000 \\
\hline & $\mathrm{N}$ & 34 \\
\hline \multirow{3}{*}{ Grammatical } & Pearson Correlation & $443^{* *}$ \\
\hline & Sig. (2-tailed) & 009 \\
\hline & $\mathrm{N}$ & 34 \\
\hline \multirow{3}{*}{ Fluency } & Pearson Correlation &, $570^{* * *}$ \\
\hline & Sig. (2-tailed) & 000 \\
\hline & $\mathrm{N}$ & 34 \\
\hline \multirow{3}{*}{ Comprehension } & Pearson Correlation &, $468^{* *}$ \\
\hline & Sig. (2-tailed) & ,005 \\
\hline & $\mathrm{N}$ & 34 \\
\hline \multirow{3}{*}{ Expression } & Pearson Correlation &, $540^{* *}$ \\
\hline & Sig. (2-tailed) & ,001 \\
\hline & $\mathrm{N}$ & 34 \\
\hline
\end{tabular}

B. The reliability of instrument

The reliability of instrument was needed to make sure that the instrument could be consistent if it was used in other time. It meant that the instrument was reliable. The instrument is computed by using SPSS version 22. The result of reliability testing by using SPSS 22 can be seen on the table 33 .

Table 3.3 Reliability Analysis

\begin{tabular}{|c|c|}
\hline Cronbach's Alpha & N of Items \\
\hline 629 & 13 \\
\hline
\end{tabular}

If the alpha Cronbach score 0.610.80 was reliable, the result of computation Alpha Cronbach's score 
https://ejournal.uniska-kediri.ac.id/index.php/PROFICIENCY

was 0.720 . it means that score categorized into reliable test.

\section{The Normality of Instrument}

The normality of instrument was shown in histogram. If the histograms had a peak, it meant that the data could be included in normal distribution. The normality was computed by using SPSS version 22 .

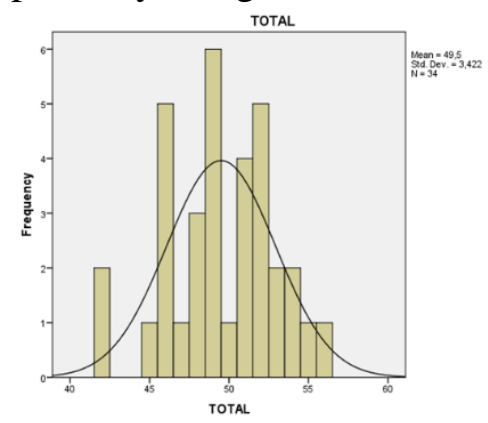

Figure 3.1 Normality Curve

Based on the figure above, it can be concluded that the data of students' writing achievement were various and distributed normally. It was proven by the peak that appeared in the diagram.

\section{Research Procedure}

This research typically involved two groups. Those groups were given different treatments. Experimental group (MIA 3) was given a new treatment; that was taught by using Whatsapp Messenger (WA). Meanwhile, control group (MIA 4) was taught by using The Picture and there have 3 meetings and one meeting for doing test. In first meeting, 1) The researcher explains the material of descriptive.

2) The researcher gives an example of descriptive. 3) The researcher asks the students to discuss the the example of descriptive teks. 4) The researcher gives the picture to be discussed. 5) The students make descriptive teks together before doing it individually. 6) The students asks the students to make whatsapp group. Each group consists of six or seven students. 7) The researcher explains the rule how to use whatsapp as a media. 8) The reseracher sends several pictures to whatsapp group. In the first treatment, the pictures are cartoon animation. 9) The students select one of the pictures to be described. 10) The students make descriptive teks individually. 11) The sudents present their description to their friend beside them. 12) The students make the vidio while presenting the descriptive teks. 13) The students send the vidio to chatroom.

The second and third was same as first meeting and the last meeting was Post-test that was given to the students in the last meeting. It means that this test was applied after the third treatment had been given. The topic for giving post-test was different from the treatment. In posttest, the theme was changed to make variation in teaching speaking. The theme is about their idol. The students had to describe and also make the video of their speech.

The activities of teacher were; opening the class by greeting and praying; giving leading question to the students about the theme while reminding them about the topic; asking the students about their idol; giving time to the students to think and prepare based on the topic; asking to the students to make video at home about their idol; collect the video by using whatsApp; closing the program for post-test.Writing test 
https://ejournal.uniska-kediri.ac.id/index.php/PROFICIENCY

was administered to get the students' scores.

Before analyzing the data, the students' writing achievements were scored based on some aspects. There are five items that are very important to be scored: After determining the score for each aspect, the total scores were gotten by using the formula below:

SCORE $=$ Pronunciation + Grammar + Vocabulary + Fluency + Comprehension + Expression.

After determining the score for each aspect, the total scores were gotten. Then, The score was analyzing by SPSS version 22 that provide descriptive the data through mean, median, mode, standart deviation, percentiles and range. To test the hypotheses, the writer also used inferential statistics, It was ttest. It was used to determine whether the is a significant difference between the means of two groups. Independent $t$-test was used in this research. The writer used SPSS version 22 to analysis of t-test. It is used to differentiate between score of experimental and control group. After finding the t-test result or t-value, the next step is interpreting it. If the significance is lower than 5\%, the difference between two groups is found and Whatsapp Messenger (WA). is effective.

\section{RESEARCH FINDING}

After the treatment was given to the experimental group that was teaching by using Silent Short Movie; while the control group was teaching without using Silent Short Movie, then the researcher conducted the post-test. From the post-test it was found the scores of experimental group (see table 4.1) and control group (see table 4.4).

Table 4.1 Statistic Data for Experimental Group

\section{A. Experimental Group}

Statistics

EXPERIMENT

\begin{tabular}{|lr|r|}
\hline \multicolumn{1}{|c|}{$\mathrm{N}$} & $\begin{array}{c}\text { Valid } \\
\text { Missing }\end{array}$ & 33 \\
Mean & & 81,15 \\
Std. Error of Mean & 1,029 \\
Median & 80,00 \\
Mode & 80 \\
Std. Deviation & & 5,911 \\
Variance & & 34,945 \\
Range & 30 \\
Minimum & & 67 \\
Maximum & & 97 \\
Sum & & 2678 \\
& 25 & 77,00 \\
Percentiles & 50 & 80,00 \\
& 75 & 83,00 \\
\hline
\end{tabular}

The highest score gotten by the students in experimental group is 97 , whereas the lowest score is 67 . The range of the highest and the lowest score is 30 . The mean score is 81,15 . The median score is 80,00 . While its mode is 80 . The standard deviation shown is 5,911 .

Frequency is number of times the scores appear in computation. There are 9 kinds of scores shown from the lowest to the highest. It means that the students' speaking achievement is various. To make it clear, the frequency of students' achievement in experimental group is presented in table 4.2 
https://ejournal.uniska-kediri.ac.id/index.php/PROFICIENCY

Table 4.2 Frequency of the Students'

Speaking Achievement in

Experimental Group

\section{EXPERIMENTAL GROUP}

\begin{tabular}{|l|r|r|r|r|}
\hline & Frequency & Percent & $\begin{array}{c}\text { Valid } \\
\text { Percent }\end{array}$ & $\begin{array}{c}\text { Cumulative } \\
\text { Percent }\end{array}$ \\
\hline 67 & 1 & 3,0 & 3,0 & 3,0 \\
70 & 1 & 3,0 & 3,0 & 6,1 \\
73 & 1 & 3,0 & 3,0 & 9,1 \\
77 & 6 & 18,2 & 18,2 & 27,3 \\
80 & 11 & 33,3 & 33,3 & 60,6 \\
83 & 6 & 18,2 & 18,2 & 78,8 \\
87 & 3 & 9,1 & 9,1 & 87,9 \\
90 & 3 & 9,1 & 9,1 & 97,0 \\
97 & 1 & 3,0 & 3,0 & 100,0 \\
Total & 33 & 100,0 & 100,0 & \\
\hline
\end{tabular}

Table 4.2 shows that; $3,0 \%$ or 1 students get $67.3,0 \%$ or 1 students get $70.3,0 \%$ or 1 student gets 73 . $18,6 \%$ or 6 students get $77.33,3 \%$ or 11 students get $80.18,2 \%$ or 6 students get $83.9,1 \%$ or 3 students get $87.9,1 \%$ or 3 students get 90 and $3,0 \%$ or 1 student gets 9 . The bar chart is presented on the figure 4.1

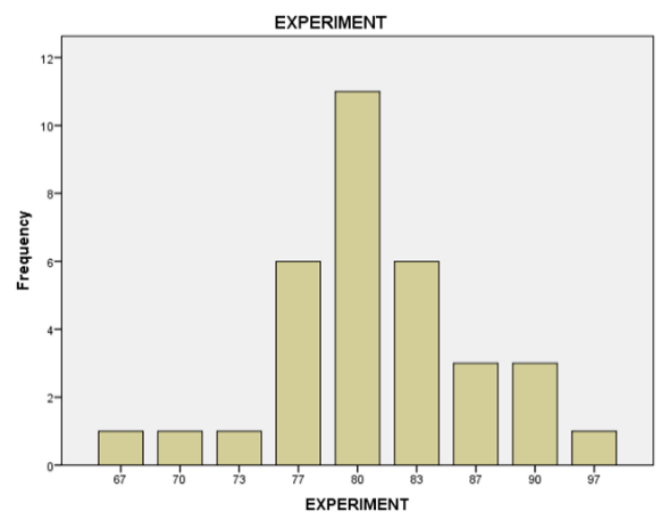

Figure 4.1 Frequency of the Students' Speaking Achievement in Experimental Group
The students' scores are classified into some categories. Table of categorization is adapted from Badan Penelitian dan Pengembangan Pendidikan Nasional Pusat Kurikulum, Depdiknas and The students' scores were categorized into some criteria as can be seen in table 4.2.

Table 4.2 Category for the Students' Achievement in Experimental Group

\begin{tabular}{|c|c|c|c|c|}
\hline No. & Score & Frequ & Percenta & Category \\
\hline 1 & $85-100$ & 7 & $21 \%$ & Very Good \\
\hline 2 & $69-84$ & 25 & $76 \%$ & Good \\
\hline 3 & $53-68$ & 1 & $4 \%$ & Fair \\
\hline 4 & $37-52$ & 0 & 0 & Bad \\
\hline 5 & $20-36$ & 0 & 0 & Very Bad \\
\hline \multicolumn{5}{|r}{} \\
\hline
\end{tabular}

The classification could make easier to show how many students got value in very good level, good level, fair level, bad level, and very bad level.

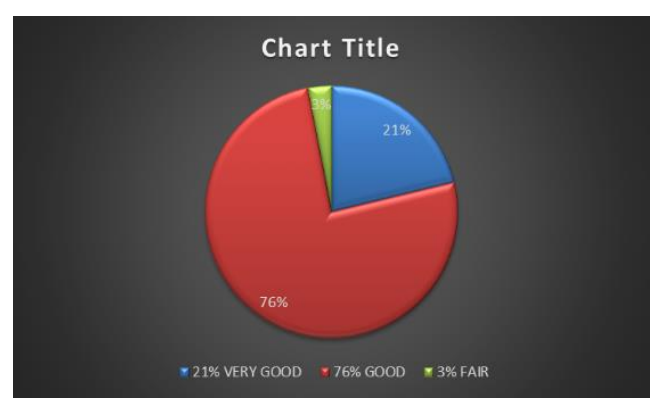

Figure 4.2 Category for the Students' Achievement in Experimental Group 
https://ejournal.uniska-kediri.ac.id/index.php/PROFICIENCY

Table 4.4 Statistic Data for Control Group

\section{B. Control Group}

Statistics

CONTROL

\begin{tabular}{|ll|r|}
\hline N & Valid & 34 \\
Mean & Missing & 0 \\
Std. Error of Mean & 70,29 \\
Median &, 765 \\
Mode & 70,00 \\
Std. Deviation & & 73 \\
Variance & 4,462 \\
Range & & 19,911 \\
Minimum & & 20 \\
Maximum & & 60 \\
Sum & & 80 \\
& 25 & 2390 \\
Percentiles & 50 & 70,00 \\
& 75 & 73,00 \\
\hline
\end{tabular}

From table 4.4 , it can be seen that the highest score is 80 and the lowest score is 60 while its range is 20. The mean shown in the group is 70,29 . The median is 70,00 while its mode is 73 . The standard deviation is 4.464 .

Frequency is number of times the scores appear in computation. There are 6 kinds of scores shown from the lowest to the highest. It means that the students' speaking achievement is various. To make it clear, the frequency of students' achievement is presented in table 4.5 on the following page.
Table 4.5 Frequency of the Students' Speaking Achievement in Control Group

\begin{tabular}{|r|r|r|r|r|}
\hline & Crequency & Percent & \multicolumn{1}{|c|}{ Valid } & Cumulative \\
\hline 60 & 2 & 5,9 & 5,9 & 5,9 \\
63 & 2 & 5,9 & 5,9 & 11,8 \\
67 & 5 & 14,7 & 14,7 & 26,5 \\
Valid & 10 & 29,4 & 29,4 & 55,9 \\
70 & 13 & 38,2 & 38,2 & 94,1 \\
73 & 2 & 5,9 & 5,9 & 100,0 \\
80 & 34 & 100,0 & 100,0 & \\
\hline
\end{tabular}

The frequencies of score achieved by the students are; $5,9 \%$ or 2 students get $60 ; 5,9 \%$ or 2 students get $63 ; 14,7 \%$ or 5 students get 70 ; $29,4 \%$ or 10 students get $70 ; 38,2 \%$ or 613 students get $73 ; 5,9 \%$ or 2 students get 80 . The bar chart is presented on the following page.

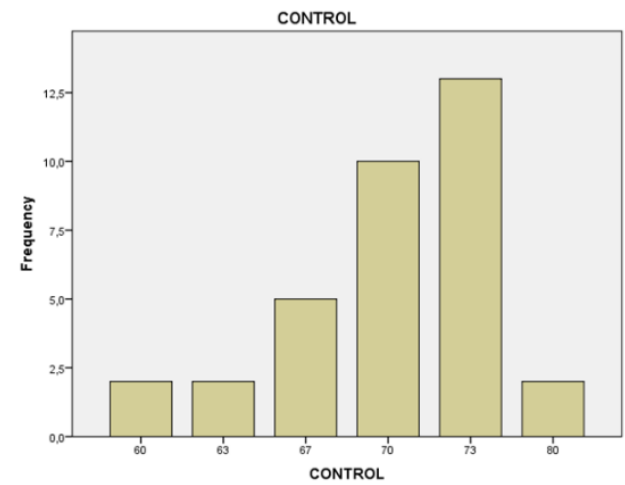

Figure 4.3 Frequency of the Students' Speaking Achievement in Control Group

The students' scores are classified into some categories. Table of categorization is adapted Badan Penelitian dan Pengembangan Pendidikan Nasional Pusat Kurikulum, Depdiknas and The students' scores were categorized into some criteria as can be seen in table 4.6. 
https://ejournal.uniska-kediri.ac.id/index.php/PROFICIENCY

Table 4.6 Category for the Students'

Achievement in Experimental Group

\begin{tabular}{|c|c|c|c|c|}
\hline No. & Score & F & Percentage & Category \\
\hline 1 & $85-100$ & 7 & $21 \%$ & Very Good \\
\hline 2 & $69-84$ & 25 & $76 \%$ & Good \\
\hline 3 & $53-68$ & 1 & $4 \%$ & Fair \\
\hline 4 & $37-52$ & 0 & 0 & Bad \\
\hline 5 & $20-36$ & 0 & 0 & Very Bad \\
\hline & Total & 33 & $100 \%$ & \\
\end{tabular}

The pie chart is presented on the following page.

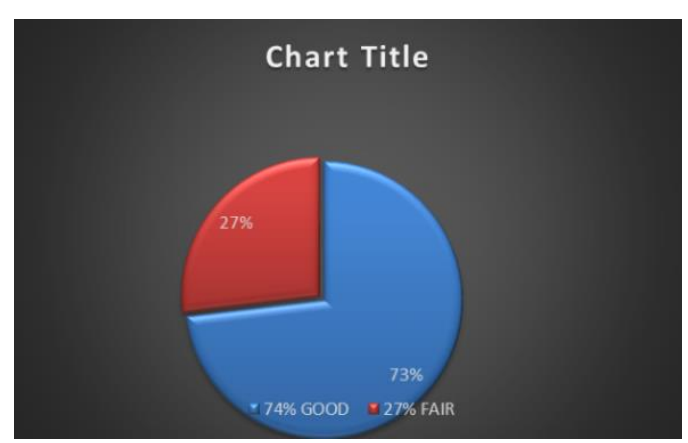

Figure 4.4 Category for the Students' Achievement in Control Group
Interpreting the Result of Significant Difference between the Students' Speaking Achievement in Experimental and Control Group

After finding the results of both groups, the significant difference between students' speaking achievement in experimental and control group is calculated. SPSS version 22 is used to analyze the data. The result is shown in table 4.7. Table 4.7 reveals a difference in mean value between the experimental group $(\mathrm{M}=81,15)$ and the control group $(M=70,29)$. In order to examine whether the experimental group and the control group differed significantly in the test achievement, an independentsample. t-test was conducted using an alpha level of .000 . The result is indicated in Table 4.8.

Table 4.7 Statistic Difference between Experimental and Control Group

\begin{tabular}{|c|c|c|c|c|c|}
\hline & GROUP & $\mathrm{N}$ & Mean & Std. Deviation & Std. Error Mean \\
\hline \multirow{2}{*}{ SCORE } & EXPERIMENTAL & 33 & 81,15 & 5,911 & 1,029 \\
& CONTROL & 34 & 70,29 & 4,462 &, 765 \\
\hline
\end{tabular}

Table 4.8 Independent Samples T-test Result Independent Samples Test

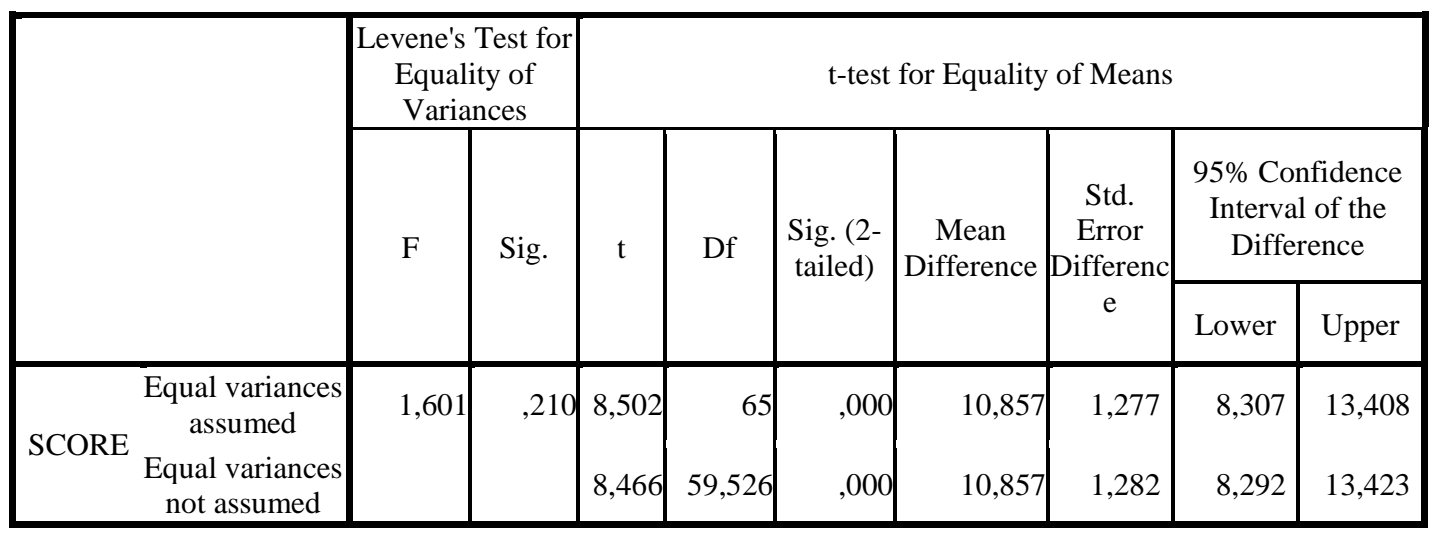


https://ejournal.uniska-kediri.ac.id/index.php/PROFICIENCY

The interpretation of the table above is; there is the significant difference between two groups if sig. (2-tailed) value is the same as or is lower than $5 \%$ or 0.05 From the sig. (2-tailed) we can see the $\mathrm{P}$ is lower than $5 \%(0.000<0.05)$. So, it can be concluded that the t-value is significant in 5\% significant level. It means that there is any significant difference between experimental and control group.

\section{The Effectiveness of Using Whatsapp Messenger (WA) in Teaching Speaking of Descriptive Text}

After knowing t-test result, we can be concluded that Alternative Hypothesis (Ha) is accepted. Alternative Hypothesis (Ha) states: Whatsapp Messenger (WA) is effective to be used in teaching descriptive text at the tenth grade of MAN 4 Kediri. Before testing this hypothesis, the t-test is calculated to compare the means between the experimental and control groups. The result reveals that experimental group outperformed the control group with significance value $0 \%$ or 0.000 as indicated in table 4.8

Significance value (sig. 2tailed) $0 \%$ or 0.000 is lower than alpha level of $5 \%$ or 0.05 . The significant difference between both groups is found. Therefore, the Null Hypothesis is rejected in favor of the Alternative Hypothesis. Thus, Whatsapp Messenger (WA) is effective to be used in teaching descriptive text at the tenth grade of MAN 4 Kediri.

\section{DISCUSSION}

The test result shows that the mean of experimental group is 81,15 whereas the mean of control group is 70,29 . The standard deviation values of both groups are 5,911 and 4.642. Meanwhile, their standard error mean values are 1,227and 765 . Furthermore, the mean difference between both groups is 10,857 .

The result shows that; 1) the mean score of experimental group $(\mathrm{M}=81,15)$ is higher than control group $(\mathrm{M}=70,29) ; 2)$ experimental group outperformed the control group with significance value $0.0 \%$ or 0.000Thus, it can be concluded that WhatsApp Messenger is effective.

\section{CONCLUTION AND SUGGESTION \\ Conclution}

1. The students' speaking achievement in experimental class at MAN 4 Kediri was in very good category with the mean 81 , 15 ,

2. The researcher had been done and the result of research had been explained clearly above. Based on the research, there are some suggestions to the teacher, students and the next researchers,

3. The students' speaking achievement in control class at MAN 4 Kediri was in good category with the mean 70,29 ,

4. The difference between the post test of experimental and control class at MAN 4 Kediri was significant. It was proved by the result of significant difference between two group if sig. (2 tailed) value is the same as or is 
https://ejournal.uniska-kediri.ac.id/index.php/PROFICIENCY

lower than $5 \%$ or 0,05 , and, $000<$ 0,05 , and

5. The effectiveness of teaching soeaking by using whatsapp messenger at MAN 4 Kediri was effective.

\section{Suggesstion}

a. For the Teacher

The teacher can use media of Whatsapp messenger as a good learning media to increase speaking skill because it has been proved that is effective and Teachers should be more creative in using Whatsapp messenger as a media, not only using it which researcher used in this research.

b. For The Headmaster

It can give a new media that can be applied in his or her school through the English teachers in order that English teachers have the same point of view in teaching other kinds of text.

c. For The Readers

This research will open the readers' mind theoritically and practically. Theoritically, it gives the new knowledge to the readers that there is significant difference of achievement between students taught by using whatsApp and students which not taught by using whatsApp.

d. For the Next Researcher It is hoped that next researcher can be more detail and complete in analyzing the usage of technique and media especially in teaching speaking so it will enrich in improving students' speaking skill.

\section{REFERENCES}

Arsyad, Azhar, Media Pembelajaran, (Jakarta: PT Raja Grafindo Persada, 2003)

Baker \& Westrup. 2003. Practical English Language Teaching: Speaking. New York: McGraw - Hill ESL/ELT.

Brown, H. Douglas, 2001. Teaching by Principles an Interactive Approach to Language Pedagogy, New York: Pearson Education.

Creswell John.W. 2014. Penelitian Kuatitatif \& Desain Riset. Yogyakarta: Pustaka Pelajar.

Fattah, Nanang. 2012. Analisis Kebijakan Pendidikan.
Bandung: PT Remaja Rosdakarya

Fauziati, Endang. 2008 .Teaching of English as a Foreign Language (TEFL). Surakarta: MUP

Harmer, Jeremy, 2001. The Practice of English Language Teaching, 3rd Ed, New York: Pearson Education Limited.

Harris, David. 1974. Testing English as a second Language. New York. MC. Graw Hill

Thornbury, Scott, 2005. How to Teach Speaking, New York: Pearson Education Limited. 